\title{
POLITIK HUKUM PADA PENANGANAN TINDAK PIDANA PEMILU
}

\author{
Diyar Ginanjar Andiraharja \\ Badan Pengawas Pemilu Kota Cimahi, Indonesia \\ Email : sutan.diyar@gmail.com
}

\begin{abstract}
The purpose of this study is to find out how the politics of law in the handling of election crime. Where the reformation of the system and the election in Indonesia is felt to be carried out half-heartedly. In practice, the handling of Election criminal acts found obstacles, based on data from 2,798 alleged Election criminal violations that were registered, then only 380 convictions regarding election criminal final cases. The research method uses the method of deductive reasoning. Furthermore, the research data are interpreted using a systematic interpretation method, which is interpreting the meaning and then linking one legal norm with another norm that is considered to have a relationship that is between legal norms that are determined as main or complementary material. The results of this study are the politics of law in the handling of election crimes to be an important factor in establishing a better election regulation. In the future, a regulation in the form of Election Law is needed that is formulated with certainty, clear, not multiple interpretations and treats all parties equally (impartial principle), then the regulation is needed to form a professional, impartial and independent law enforcer in carrying out law enforcement functions. Elections that are clearly regulated.
\end{abstract}

Keywords: Election Criminal Acts, Legal Politics, Regulations

\begin{abstract}
Abstrak
Tujuan penelitian ini adalah untuk mengetahui bagaimana politik hukum pada penanganan tindak pidana Pemilu. Di mana pada reforrmasi pada sistem dan Pemilu di Indonesia dirasakan masih dijalankan setengah hati. Pada praksisnya penanganan tindak pidana Pemilu menemukan hambatan, berdasarkan data dari 2.798 dugaan pelanggaran pidana Pemilu yang diregistrasi, kemudian hanya 380 putusan perkara incrahct pidana Pemilu. Metode penelitian menggunakan metode penalaran deduktif. Selanjutnya, data penelitian ditafsirkan menggunakan cara penafsiran sistematis, yakni menginterpretasi makna lalu mengaitkan norma hukum yang satu dengan norma lain yang dianggap memiliki keterkaitan yakni antara norma-norma hukum yang ditentukan sebagai bahan utama maupun pelengkap. Hasil penelitian ini yakni politik hukum dalam penanganan pidana Pemilu menjadi faktor yang penting untuk membentuk suatu regulasi Pemilu yang lebih baik. Ke depan dibutuhkan suatu regulasi berbentuk undang-undang Pemilu yang dirumuskan secara pasti, jelas, tidak multitafsir dan memperlakukan semua pihak secara setara (prinsip imparsial), kemudian regulasi tersebut dibutuhkan untuk membentuk penegak hukum yang profesional, imparsial, dan independen dalam menjalankan fungsi penegakan hukum Pemilu yang diatur secara jelas..
\end{abstract}

Kata Kunci: Politik Hukum, Regulasi, Tindak Pidana Pemilu

\section{PENDAHULUAN}

Fungsi Pemilu itu terdiri dari dua perspektif (Kartini, 2017), yakni dari perspektif bottom-up yakni : 1) instrument pelibatan politik, yakni setiap rakyat yang memiliki hak, dapat diseleksi menjadi pejabat negara; 2) sebagai instrument penyusunan rezim; dan 3) instrument untuk mengerem tingkah laku penguasa dan kebijakannya. Kemudian dari sudut pandang top-down yakni fungsi Pemilu sebagai : 1)

* Copyright (c) 2020 Diyar Ginanjar Andiraharja

This work is licensed under a Creative Commons Attribution-ShareAlike 4.0 International License.

Diterima: 2 Februari 2020; Direvisi: 24 April 2020; Disetujui: 27 April 2020 
sarana membangun legitimasi; 2) instrumen konsolidasi dan rotasi elit secara berkala; 3) instrumenuntuk mempersiapkan representasi; 4) sebagai instrumenedukasi politik.

Pemilihan Umum serentak tahun 2019 telah membuktikan negara Indonesia telah berhasil dalam penyelenggaraannya pada 17 April 2019 silam (Siregar, 2019). Dari Pemilu serentak ini telah mengantarkan Ir. H. Joko Widodo sertaK.H. Ma'ruf Amin menjadi pasangan Presiden dan Wakil Presiden Republik Indonesia, kemudian telah mengantarkan 575 orang perwakilan untuk Dewan Perwakilan Rakyat RI dan 136 orang perwakilan untuk Dewan Perwakilan Daerah RI menuju Senayan, selanjutnya 2.207 orang perwakilan untuk Dewan Pewakilan Rakyat Daerah Provinsi dan 17.060 orang perwakilanuntuk Dewan Perwakilan Rakyat Daerah Kabupaten/Kota.

Meskipun dapat dikatakan berhasil, namun bukan berarti pelaksanaan Pemilu tahun 2019 nihil masalah atau terlaksana tanpa terjadinya pelanggaran. Tercatat sampai dengan 28 Mei 2019, Bawaslu menampung 15.052 laporan atau temuan dugaan pelanggaran selama Pemilihan Umum tahun 2019. Dari 15.052 tersebut sejumlah 14.462 merupakan hasil temuan dari Bawaslu sendiri yang aktif melakukan pengawasan.

Terdapat 2.798 dugaan pelanggaran pidana Pemilu yang diregistrasi, kemudian 582 kasus yang diteruskan ke penyidikan, lalu terdapat 409 kasus yang diteruskan ke tahap penuntutan dan selanjutnya telah ada 380 putusan perkara incraht pidana Pemilu.

Selama pelaksanaan Pemilu 2019, selain pelanggaran Pemilu yang ditangani Bawaslu, terdapat pula sengketa pada proses Pemilihan Umum, dan sengketa hasil Pemiliham Umun. Ranah penanganan dan penindakan tindak pidana Pemilu, pelanggaran proses administrasi Pemilihan Umum dan sengketa proses Pemilihan Umum ada pada lembaga Bawaslu. Untuk penanganan pelanggaran kode etik penyelenggara Pemilihan Umum diproses dan diputus oleh Dewan Kehormatan Penyelenggara Pemilu. Untuk perselisihan hasil Pemilihan Umum, lembaga yang memproses dan menyelesaikan adalah Mahkamah Konstitusi (Satrio, 2016).

Terdapat 15 standar internasional dalam penyelenggaraan Pemilu (International Standard on Elections) yang disusun IDEA (International Institute for Democracy and Electoral Assistance) tahun 2002 yakni: 1) penyusunan kerangka regulasi; 2) pemilihan cara Pemilu; 3) penentuan daerah pemilihan: 4) hak untuk memilih serta dipilih; 5) institusipelaksana Pemilu; 6) pendataan pemilih dan daftar pemilih; 7) akses suara bagi partai politik dan kandidat; 8) kampanye Pemilu yang demokratis; 9) aksesuntuk media dan transparansi informasi dan kemerdekaan bersikap; 10) biaya kampanye dan penganggaran kampanye; 11) pengambilan suara; 12) rekapitulasi suara dan tabulasi suara; 13) fungsi keterwakilan partai politik dan kontestan; 14) pemantau pemilu; 15) ketaatan terhadap regulasi serta penegakan hukumPemilu.

Kemudian terdapat 20 International Obligations on Elections di tahun 2014 oleh IDEA yakni: 1) Hak dan kesempatan untuk turut serta dalam kepentingan umum; 2) Hak dan kesempatanuntukmemilih; 3) Hak dan kesempatan untuk dipilih; 4) Pemilihan yang periodik; 5) Hak pilih yang universal; 6) Hak pilih yang sama; 7) Jaminan kerahasiaan dalam pemungutan suara; 8) Kebebasan dari diskriminasi dan kesetaraan di mata hukum; 9) Kesetaraan hak antara laki-laki dan perempuan; 10) Kemerdekaan untuk berserikat; 11) Kemerdekaan untuk berkumpul; 12) Kebebasan untuk bertindak; 13) Kebebasan berpendapat dan berekspresi; 14) Hak atas keamanan; 15) Keterbukaan dan hak atas informasi; 16) Pencegahan dari korupsi; 17) Aturan hukum; 18) Hak atas pemulihan yang efektif; 19) Hak atas persidangan yang adil dan terbuka; dan 20) Negara mesti mengambil langkah-langkah yang diperlukan untuk melindungi hak. 
Jika kita cermati maka, dari 20 kewajiban internasional ini ditimbang lebih menjamin keterlaksanaan Pemilu yang demokratis dibanding dengan 15 standar pada tahun 2002, dalam 20 kewajiban internasional ini sudah terdapat jaminan dalam hal:

1) Right to security (kewajiban ke 14);

2) Prevention of corruption (kewajiban ke 16);

3) Rule of law (kewajiban ke 17);

4) Right to effective remedy (kewajiban ke 18); dan

5) State must take necessary steps to give effect to right (kewajiban ke 20).

Selanjutnya dalam 21 Component of Legislation on Elections (International IDEA 2014) yakni: 1) Structure of the legal framework;2) Sistemkepemiluan;3) Electoral boundaries; 4) partai politik; 5) Political finance; 6) manajemen kepemiluan; 7) Kesetaraan gender; 8) Equal opportunities for minorities and marginalized groups; 9) Equal opportunities for persons with disabilities; 10) Electoral observers; 11) Civic and voter education; 12) Voter eligibility; 13) Voter registration; 14) Pendaftaran para kandidat; 15) Media environment; 16) Kampanye Pemilu; 17) Kampanye di media; 18) Jajak pendapat; 19) Counting and result management; 20) Keadilan Pemilu; 21) PelanggaranPemilu.

Pada poin pertama, kerangka hukum pemilu di Indonesia sudah berusaha mengadopsi standar/komponen Pemilu demokratis sebagaimana telah ditentukan.Kemudian pada poin 20, Indonesia sudah memiliki suatu electoral justice system. Kedua hal ini bukan hanya menjamin suatu hasil Pemilu saja, namun beupa integritas hasil dan integritas seluruh proses Pemilu. Sedangkan electoral offences dapat didefinisikan sebagai "Suatu tindakan atau kelalaian yang didefinisikan sebagai tindak pidana, biasanya melalui pemilihan atau hukum pidana umum. Contohnya termasuk penipuan, paksaan, halangan atau pemalsuan pendaftaran pemilih, dan pelanggaran ketentuan dana kampanye."

Berdasarkan uraian di atas bentuk partisipasi masyarakat atas terselenggaranya Pemilu dalam aspek penegakan keadilan Pemilu dirasa masih minim. Terlihat dari data persentase laporan masyarakat pada penyelenggaraan Pemilu tahun 2019 yang masih timpang dengan temuan. Kemudian dari potret penanganan pelanggaran pidana Pemilu tahun 2019 yakni dari 3.725 temuan dan laporan dugaan pidana Pemilu, pada akhirnya 380 kasus saja yang incraht.

\section{METODE PENELITIAN}

Menggunakan pendeketan Kualitatif (Sugiyono, 2013), data diolah dari proses pengumpulan bahan-bahan kepustakaan, lalu diseleksi guna menghasilkan data khusus yang berhubungan dengan topic masalah yang dikaji, selanjutnya memilah data dalamaspek hukum secara berurutan dan logis.

Data makalah ini disusun dan dianalisis dengan menggunakan metode penalaran deduktif. Selanjutnya, data tersebut ditafsirkan menggunakan cara penafsiran sistematis, yakni menginterpretasi makna lalu mengaitkan norma hukum yang satu dengan norma lain yang dianggap memiliki keterkaitan yakni antara norma-norma hukum yang ditentukan sebagai bahan utama maupun pelengkap dalam makalah ini.

\section{HASIL DAN PEMBAHASAN}

Walaupun Indonesia telah hampir dua puluh tahun melalui era Reformasi, sampai saat ini suatu desain sistem dan hukum Pemilu di Indonesia belum disusun secara komprehensif serta koheren yang manfaatnya dapat berlaku dalam jangka panjang. Dengan kata lain reformasi pada sistem dan hukum Pemilu di Indonesia masih dijalankan setengah hati. 


\section{Khazanah Hukum, Vol. 2 No. 1: 24-31}

Politik Hukum pada Penanganan Tindak Pidana Pemilu Diyar Ginanjar Andiraharja

Menurut Wirdyaningsih (2019) ada 4 (empat) permasalahan dalam tindak lanjut penyelesaian pelanggaran pidana PemilihanUmum yakni: 1) regulasi dalam perundang-undangan yang tidak jelas dan tidak holistik; 2) adanya perbedaan penafsiran antar aparatur penegak hukum dalam Sentragakkumdu (penyidik dan jaksa) dengan Bawaslu; 3) ketidaksiapan, ketidakmampuan, dan ketidakmauan penegak hukum dalam menangani pelanggaran pidana Pemilu; 4) koordinasi antar jajaran pengawas Pemilu, penyidik dan jaksa yang tidak efektif.

Selanjutnya menurut Fahmi (2019) terdapat dua permasalahan dalam penegakan hukum pemilu yakni regulasi dan penegakan hukum Pemilu. Permasalahan regulasi yakni ketidakpastian dalam rumusan norma undang-undang Pemilu, khususnya terkait masalah hukum Pemilu. Kemudian pada permasalahan penegakan hukum Pemilu berupa permasalahan dalam fungsi, hubungan, dan perspektif masing-masing lembaga penegakan hukum Pemilu.

Menurut Kania (2019), terdapat dua problematika dalam penyelesaian tindak pidana Pemilu yakni: 1) problem dalam regulasi tindak pidana Pemilu, yakni pada hukum materilnya serta hukum acaranya sehingga mengganggu penyelesaian penegakan hukum pidana itu sendiri; 2) problem dalam hukum materiil pada penggolongan tindak pidana Pemilihan Umum, sedangkan problem dalam hukum acara ada pada proses penyelesaian tindak pidana Pemilihan Umum.

Selanjutnya menurut Kania (2019) terdapat permasalahan dalam mekanisme penanganan tindak pidana Pemilu yakni : 1) pada satu sisi undang-undang Pemilu menetapkan bahwa mekanisme penyelesaian tindak pidana Pemilu merujuk pada Kitab Undang-UndangHukum Acara Pidana, namun di lain pihak undang-undang Pemilihan Umum membuat mekanisme penanganan yang berlainan dengan pada Kitab Undang-Undang Hukum Acara Pidana; 2) dari aspek norma, regulasi Undang-Undang Pemilu belum cukup terang dan utuh dalam menata aspek hukum materiil dan hukum acara; 3) regulasi pada undang-undang Pemilu disinyalir dominan akan kepentingan politik yang menuju pada pengingkaran; 4) hukum materiil dan hukum acara pada tindak pidana Pemilu belum detildan rigid sehingga mendatangkan perdebatan tafsir yang mengganggu pelaksanaan penegakan hukum pidana Pemilu.

Implikasi logis dari kondisi ketidakjelasan dalam batasan dan norma pada undang-undang Pemilu adalah adanya perbedaan interpretasi antara aparat penegak hukum dan Bawaslu, muaranya sendiri adalah terganggunya proses penyelesaian tindak pidana Pemilihan Umum.

Hakikat dari penegakan hukum Pemilihan Umum khususnya penanganan tindak pidana Pemilihan adalah untuk menegakkan keadilan Pemilu. Keadilan sendiri menurut Kelsen (2014) sebagai suatu kondisitertib sosial yang mampu memastikan usaha pencarian kebenaran dapat berkembang optimal. Keadilan mempresentasikan suatu kebebasan, perdamaian, demokrasi, serta toleransi.

Selanjutnya John Rawls mengungkapkan keadilan sebagai fairness, memiliki asas bahwa orang yang bebas dan rasional mesti mendapat suatu posisi yang sama ketika memulai keinginan untuk mengembangkan kepentingannya. Keadilan tidak hanya mencakup konsep moral tentang individu tetapijuga tentangcara mendapat keadilan itu sendiri.

Uraian yang menjadi penting dalam konteks ini adalah terkait politik hukum pada regulasi tindak pidana Pemilu. Yakni jika mengacu pada UU nomor 7 Tahun 2017 tentang Pemilihan Umum memiliki 77 pasal tindak pidana Pemilu. Masalahnya apakah dengan sanksi-sanksi tersebut telah efektif dalam meminimalkan pelanggaran pidana Pemilu? Kemudian apakah sanksi-sanksi pada pelanggaran pidana Pemilu dapat ditegakkan secara efektif?

Menurut Soerjono Soekanto dalam (Devilla \& Tarmizi, 2018) menjelaskan bahwa efektifitas penegakan hukum bergantung pada beberapa faktor yaitu: 1) substansi hukum itu sendiri; 2) aparat 
penegak hukum; 3) sarana; 4) budaya hukum. Titik tekan pada pembahasan ini pada regulasi undangundang Pemilu itu sendiri yang menuntun para pelaksananya dalam penanganan tindak pidana Pemilu.

L.J.Van Apeldorn menyatakan politik hukum merupakanpolitik perundang-undangan. Politik hukum menentukan tujuan serta isi peraturan perundang-undangan.

Politik hukum merujuk pendapat Satjipto Rahardjo adalah kegiatan untuk memutuskan suatu opsi mengenai tujuan serta metode-metode yang hendak digunakan dalam mencapai tujuan hukum dalam masyarakat.

Mahfud MDmenyatakan, politik hukum merupakan legal policy atau arah kebijakan resmi mengenai hukum yang akan diterapkan baik dengan pembuatan hukum baru maupun dengan penggantian hukum lama, dengan maksud untuk mencapai tujuan negara.

Tindak pidana sendiri adalah masalah sosial yang dapat merugikan dan menimbulkan korban. Ada pun spektrum tindak pidana luas cakupannya, mulai dari tindak pidana umum , hingga tindak pisana khusus yang diatur di berbagai undang-undang pidana khusus di luar KUHP. Ada pun penanggulangan tindak pidana dapat ditangani dengan sarana non hukum pidana maupun melaluialathukum pidana.

Penanganan melalui jalurnon hukum pidana dapat dilakukan lewat suatu upaya penecegahan dan pengurangan faktor penyebab kejahatan itu sendiri seperti penguatan kemampuan daya beli di bidang ekonomi, pendidikan, sosialisasi tentang regulasi, penanaman nilai-nilai keagamaan, penguatan ikatan sosial dalam masyarakat,serta meningkatkan sarana atau peralatan untuk mencegah kejahatan terjadi.

Penanggulangan kejahatan pun dapat dilakukan dengan hukum pidana, misal dengan proses kriminalisasi suatu perbuatan melalui perundang-undangan, melalui suatu ancaman hukuman, penguatan lembaga-lembaga penegak hukum, penegakan hukum atas kejahatan yang terjadi, membuat suatu undang-undang tertentu serta mengubah undang-undang pidana.

Tindak pidana Pemilu menurut UU nomor 8 Tahun 2012 tentang Pemilu Anggota DPR, DPD , DPRD menyatakan sebagai suatu pelanggaran terhadap ketentuan pidana Pemilu yang diatur dalam undangundang, dimana penyelesaiannya dilaksanakan melalui pengadilan dalam lingkungan peradilan umum.

Definisi tindak pidana Pemilu sendiri tidak terdapat pada UU No.7 Tahun 2017 tentang Pemilu, definisi ini muncul pada Perbawaslu nomor 7 Tahun 2018 Pasal 1 angka 31 menyatakan bahwa tindak pidana Pemilu merupakan tindak pidana pelanggaran dan/atau kejahatan terhadap ketentuan tindak pidana Pemilu sebagaimana diatur dalam Undang-Undang tentang Pemilihan Umum.

Topo Santoso menyatakan tindak pidana Pemilu merupakan tindakan aktif atau pasif yang melanggar norma dalam tahapan-tahapan penyelenggaraan Pemilihan Umumyang diancam dengan sanksi pidana dalam undang-undang Pemilu.

Jika diperhatikan pada UU nomor 7 Tahun 2017 tentang Pemilu, ada sejumlah 77 pasal tindak pidana Pemilihan Umum, kemudian diatur di 66 pasal aturan pidana. Jika dianalisa maka jumlah ini meningkat jika dikomparasi dengan UU nomor 8 Tahun 2012 yaitu sejumlah 48 pasal.

Subjek hukum dari tindak Pidana Pemilu ada beberapa kategori yakni delik komun "setiap orang" sebanyak 22 tindak pidana dari 77 tindak pidana Pemilu. Sisanya 55 tindak pidana merupakan delik propria, yang subjeknya tertentu/tidak setiap orang, mulai dari penyelenggara Pemilu tingkat bawah sampai tingkat atas, pejabat negara, penegak hukum dan lain-lain. Terdapat 23 tindak pidana Pemilihan Umum dari 77 tindak pidana Pemilu yang subjeknya merupakan penyelenggara Pemilu itu sendiri. Sedangkan bagi pelaksana kampanye Pemilu, peserta kampanye Pemilu, peserta Pemilu, calon Presiden dan wakil Presiden serta pimpinan partai Politik menjadi subjek pada 13 tindak pidana Pemilu.

Dari data tersebut secara kuantitas lebih banyak tindak pidana yang diancamkan diterapkan pada penyelenggara Pemilu jika dibandingkan subjek yang lain. Hal ini menjadi beban tersendiri bagi 


\section{Khazanah Hukum, Vol. 2 No. 1: 24-31}

Politik Hukum pada Penanganan Tindak Pidana Pemilu

Diyar Ginanjar Andiraharja

penyelenggara Pemilu, selain dengan beban tanggung jawab yang berat, mereka juga dihantui dengan banyaknya ancaman pidana.

Kemudian hukuman yang diterapkan bagi orang yang melakukan suatu tindak pidana Pemilu ada beberapa kategori yakni ancaman pidana penjara, kurungan, dan denda. Di mana sanksi pidana penjara dan denda dapat diterapkan secara kumulatif. Namun terdapat kekurangan pada regulasi ini yakni tidak dinyatakan secara tegas tindak pidana mana yang dikategorikan kejahatan dan mana yang dikategorikan sebagai pelanggaran.

Jika ditinjau dari segi unsur kesalahan, maka dapat dilihat tindak pidana Pemilu ada yang termasuk unsur kesalahan berupa dengan sengaja atau disebut juga sebagai delik dolus. Kemudian ada juga unsur kesalahan berupa kealpaan/kelalaiam yang disebut juga sebagai delik culpa. Selanjutnya ada satu delik proparte dolus proparte culpa karena ada unsur sengaja dan kealpaan sekaligus dalam pasal tersebut. Dalam UU No. 7 Tahun 2017 tentang Pemilu, yang jelas-jelas menggunakan unsur dengan sengaja sebanyak 42 tindak pidana, dari 77 delik pidana Pemilihan Umum.Selain 42 delik pidana yang delik dolus, ada juga terkait delik dolus tetapi tidak menggunakan kata sengaja, melainkan menggunakan kata lainnya yang dapat ditafsirkan dengan sengaja.

Pada Pasal 491 yang ada unsur seperti: mengacaukan, menghalangi, atau mengganggu jalannya kampanye Pemilu. Mencermati unsur ini dapat disimpulkan sebagai delik dolus. Selanjutnya terdapat 4 tindak pidana yang jelas menggunakan unsur karena kelalaian/kealpaan. Pasal 550 memiliki unsur dengan sengaja dan unsur karena kelalaian, sehingga dapat disimpulkan Pasal 550 merupakan delik proparte dolus proparte culpa.

Berdasarkan pembahasan di atas penegakan hukum Pemilihan Umum khususnya adalah hal yang esensial dalam pelaksanaan Pemilihan Umum. Penegakan hukum Pemilihan Umum ini bertujuan mencapai suatu keadilan Pemilihan Umum, sebagai halnya kerangka keadilan hukum yang tersusun atas keadilan prosedural (formil) serta keadilan substantif (materil). Kedua keadilan ini saling berkelindan dan tidak bisa dipilah berdasar prioritas pemenuhannya. Tercapainya rasa keadilan ini akan bermuara pada kepercayaan publik atas terselenggaranya Pemilu, karena publik yakin bahwa Pemilu yang dilaksanakan adalah Pemilu yang berintegritas.

Untuk mengatasi permasalahan dalam penanganan tindak pidana Pemilu setidaknya diperlukan politik hukum dalam arah kebijakan legislasi penegakan hukum Pemilu, merujuk pada naskah akademik UU No.7 Tahun 2017 tentang Pemilu setidaknya terdapat dua tujuan dasar dilaksanakannya Pemilu yakni: 1) menciptakan pemerintah yang stabil yang dihasilkan dari keselarasan hasil pemilihan Presiden dan pemilihan legislatif; 2) memberi ruang pada pemilih agar lebih cerdas dalam memilih.

Menurut Sera (Sera, 2019), arah Pemilu ke depan diperlukan iktikad dalam politik hukum untuk suatu konsolidasi demokrasi yakni: 1) membangun demokrasi substantif dan berkualitas yang bermakna terwujudnya suatu merit system; 2) terwujudnya kepemimpinan yang sehat, demokrasi murah dan berkualitas; 3) merevisi aturan yang mengekang kebebasan berserikat dan berpendapat; 4) merevisi keputusan/kebijakan yang melanggar asas keadilan dan demokrasi; 5) mewujudkan tiga dimensi demokrasi yaitu: 1. kemerdekaan sipil; 2.hak-hak dalam politik; dan 3. institusi demokrasi.

Kemudian mengupayakan sistem politik yang mantap, dinamis, dan tepat guna yakni dengan: 1) mengubah sistem politik berbiaya tinggi menjadi sistem politik yang lebih terjangkau; 2) Merevisi UU Pemilu untuk pelaksanaan Pemilu yang demokratis dan berbiaya rendah, dengan batas Presidential Treshold 7\% dan batas Parlementary Treshold 7\%; 3) merevisi UU Partai Politik untuk melakukan pembaruan kepartaian dengan penerapan tata kelola partai yang baik dan optimalisasi pendanaan partai 
yang terbuka dan dapat dipertanggungjawabkan; 4) mewujudkan institusi legislatif, eksekutif, dan yudikatif yang beretika, berkapasitas, dan efisien.

Menurut Lukman (2017), konsolidasi demokrasi akan sulit tercapai apabila politik uang masih mewabah, sebab demokrasi yang pada dasarnya adalah cara bernegara yang dilandaskan pada cara pandang bahwa kedaulatan sepenuhnya ada pada rakyat, selaras dengan peribahasa "Suara rakyat adalah suara Tuhan". Politik uang dapat dianggap sebagai racun demokrasi, yang dapat mematikan nilai-nilai demokrasi. Selain masyarakat yang berpotensi rusak, aparat negara, bahkan hukum dapat rusak.

Selanjutnya Lukman (2017 )menyatakan dalam berbagai kajian, politik uang dapat disebabkan oleh: 1) rendahnya pendidikan politik; 2) sebagai ekspresi kekecewaan masyarakat yang menilai parlemen tidak pro rakyat, akibatnya mayoritas masyarakat beranggapan siapapun yang terpilih, nasib mereka tidak akan berubah; 3) lemahnya penegakan hukum yang dapat menjerat praktik politik uang.

Untuk menjamin harapan ke depan, dalam mengurangi praktik politik uang, maka diperlukan iktikad bersama dalam politik hukum dalam bentuk jaminan prosedural penanganan tindak pidana Pemilu yakni: 1) akses pada prosedur penanganan keadilan PemilihanUmum yang integral dan tepat guna; 2) keadilan Pemilu minus pembiayaan atas jasa dengan ongkos yang rasional; 3) vonis atau penanganan yang segera dan tepat waktu agar pelanggaran dapat dikoreksi; 4) hak untuk dibela, menghadiri persidangan, dan mendapat penanganan hukum yang adil; 5) putusan dan ketetapan yang dijalankan seutuhnya dan tepat waktu; dan 5) undang-undang Pemilihan Umum yang diinterpretasikan dan diaplikasikan secaraterus-menerus.

\section{SIMPULAN}

Dari pembahasan tersebutmaka ditarik kesimpulan bahwa politik hukum dalam penanganan pidana Pemilu menjadi faktor yang penting untuk membentuk suatu regulasi Pemilu yang lebih baik. Ke depan dibutuhkan suatu regulasi berbentuk undang-undang Pemilu yang dirumuskan secara pasti, jelas, tidak multitafsir dan memperlakukan semua pihak secara setara (prinsip imparsial), kemudian regulasi tersebut dibutuhkan untuk membentuk penegak hukum yang profesional, imparsial, dan independen dalam menjalankan fungsi penegakan hukum Pemilu yang diatur secara jelas. Akhirnya proses penegakan hukum Pemilihan Umum menjadi sebuah prosedur yang diaplikasikan secara kontinu, dimulai dari tahap persiapan, pelaksanaan, dan evaluasi.

\section{DAFTAR PUSTAKA}

Devilla, F. A., \& Tarmizi, T. (2018). Penerapan Sanksi Pidana Terhadap Kendaraan Yang Tidak Laik Jalan Karena Telah Dimodifikasi. Jurnal Ilmiah Mahasiswa Bidang Hukum Pidana, 2(4), 735745.

Edy, M. L. (2017). Konsolidasi demokrasi Indonesia: original intent undang-undang pemilu. RMBooks.

Fahmi, K. (2019). Menata Penegakan Hukum Pemilu yang Berkeadilan. Jakarta.

Kania, D. (2019). Keadilan Pemilu dalam Penanganan Tindak Pidana Pemilu dan Pilkada. Bandung.

Kartini, D. S. (2017). Demokrasi dan Pengawas Pemilu. Journal of Governance, 2(2).

Kelsen, H. (2014). Teori Umum Tentang Hukum dan Negara, Diterjemahkan dari buku Hans Kelsen: General theory of law and state, penerjemah Raisul Muttaqien. Penerbit Nusa Media.

Satrio, A. (2016). Kewenangan Mahkamah Konstitusi Memutus Perselisihan Hasil Pemilu Sebagai Bentuk Judicialization Of Politics. Jurnal Konstitusi, 12(1), 117-133.

Sera, M. A. (2019). Arah Kebijakan Legislasi Penegakan Hukum Pemilu. Jakarta.

Siregar, M. (2019). Membaca Hasil Pemilu Indonesia Tahun 2019. An1mage. 
Khazanah Hukum, Vol. 2 No. 1: 24-31

Politik Hukum pada Penanganan Tindak Pidana Pemilu

Diyar Ginanjar Andiraharja

Sugiyono. (2013). Metode Penelitian Pendidikan Pendekatan Kauntitatif, kualitatif dan R\&D. Bandung: Alfabeta.

Wirdyaningsih. (2019). Dinamika Penegakan Hukum Pemilu. Jakarta. 